\title{
Consumers' Internet Shopping Decision toward Fashion Apparels and Its Impact on Satisfaction in Bangladesh
}

\author{
Afzal Hossain \\ MBA Student, Department of Marketing, Comilla University, Comilla, Bangladesh
}

\section{Md. Lutfar Rahman}

$\mathrm{PhD}$, Malaysia University of Science and Technology; Professor, College of Business Administration, International University of Business Agriculture and Technology, Dhaka, Bangladesh

\section{Md. Moynul Hasan}

MBA, Rajshahi University; Assistant Professor, Department of Marketing, Comilla University, Comilla, Bangladesh

\begin{abstract}
This paper aims to analyze the consumers' internet shopping decision toward fashion apparels and its impact on satisfaction in Bangladesh. This paper adopts the quantitative analysis of possible factors that may affect consumers' internet shopping decision of fashion apparels and its impact on satisfaction. By using convenient sampling method, the data has been collected from 200 respondents. Data are analyzed using frequency \& regression analysis. From the results of regression analysis, this research is found that security, delivery, product availability, and product variety as the important factors, which significantly influence consumers' internet shopping decision of fashion apparels. This study revealed that internet shopping decision of fashion apparels as the vital factor, which significantly affects consumers' satisfaction on fashion apparels. This paper may be added to these internet shopping focuses on fashion apparels. Internet functioning fashion apparels organization can be promoted recognizing persuasive factors of internet shopping decision and satisfaction on fashion apparels. It can aid internet shopping decision of fashion apparels and satisfaction on fashion apparels excellence along with numerous apparels offer to virtual consumers through the internet. This exploration will be created awareness among e-business practicing fashion apparels firms, academicians, researchers, and virtual fashion apparels shoppers.
\end{abstract}

Keywords: Internet shopping decision, fashion apparels, satisfaction, influential factors, Bangladesh.

JEL Classification: D11, L81, C44.

Cite as: Hossain, A., Rahman, Md. L., Hasan, Md. M. (2018). Consumers' Internet Shopping Decision toward Fashion Apparels and Its Impact on Satisfaction in Bangladesh. Business Ethics and Leadership, 2(4), 74-82. http://doi.org/10.21272/bel.2(4).74-82.2018.

(C) The Authors, 2018. This article is published with open access at Sumy State University.

\section{Introduction}

E-commerce speedy progress and internet group shopping activities mostly swift, suitable and without geographical constraint to involve in a purchasing activity to gain notable discounts, get better the level of demand, to bargain with vendors to attain a deal at a lower price and a collection of negotiation, distribution consolidation formation, initiator voting and payment collection (Sien, 2015). E-commerce may be defined as the eagerness to share personal information over the internet that allows for a business deal as regards a shop to be prepared (Bélanger et al., 2002). E-commerce is an instrument for diminishing streaming business processes, cycle time, administrative costs and improving relationships with both consumers and business partners. The study depicted that factors influencing consumer's intention and future shop to make e-commerce shops through internet shopping consumers' helpful or harmful thoughts related to executing the shopping actions on the Internet (Chiu et al., 2005). Majority of consumers predominantly $60.20 \%$ visit a particular ecommerce website by clicking promoted link such as Facebook, Twitter, Google, Yahoo search engines, public mail servers etc. So, e-commerce sites ought to be promoted on target websites (Bulbul, 2015). Commerce has truly made a business situation in our contemporary world through equipment like the internet or other computer networks. The development of internet shopping is fundamentally depending on the user-friendliness of the internet of the consumers. In e-commerce, the payment is actually a difficult part after shopping services. Information technology can play a noteworthy role in developing and increasing the excellence of services in business sectors. Though the majority of the people of Bangladesh particularly the rural people are not enough 
capable of operating the internet to run the internet business (Mohd, 2017). Shoppers' internet shopping decision is a momentous guide for functioning internet business in Bangladesh. The main purpose of this paper is to discover the key factors that influence consumers' intention, satisfaction, and loyalty towards internet shopping in Bangladesh. The study is found that security, personal hobby, payment method, appropriate pricing, privacy, social media and reference groups as the significant factors, which considerably influence consumers' internet shopping decision in Bangladesh. The exploration is revealed that online purchases intention, product quality, and product brand as important factors, which significantly influence consumers' satisfaction. The paper is also demonstrated that satisfaction as the momentous factor, which notably influences consumers loyalty in Bangladesh (Hossain, A. et al., 2018). The inspiration behind this paper is to decide purchasers' recognition towards internet shopping with a specific focus on accommodation and security on apparel purchaser market in Bangladesh. The findings add esteem to present writing as well as mention, may influence the development of fate of capability of internet shopping of apparel items in Bangladesh.

The present scenario of e-commerce is favoring internet shopping of essential commodities greatly. Thus, fashion apparel shopping is trendy activities of e-commerce shoppers. Internet shopping is rising gradually. Internet shopping is speedy becoming the approach to formulate all shops at home or in the office or in a different country. Internet shopping has become a familiar phenomenon around the world. Bangladesh is not so far behind in this case. Internet shopping is in a competition with traditional shopping. Thus, a superior quantity of internet shops is receiving inaugurated in this country and the taking of internet shopping in Bangladesh is also rising (Jubayer, 2015). In Bangladesh, internet shopping would acquire more attention from consumers because shopping from internet provides several benefits to consumers such as shopping from their place, reduced transportation cost, a wide variety of choices (Qazi, 2014). This movement to shop internet from the comfort of own couch has newly been taken up in the Asian region as well, especially in Bangladesh. The purpose of the study is to analyze the consumers' internet shopping decision toward fashion apparels and its impact on satisfaction in Bangladesh.

Achieving the objective, this paper is allocated into the following segments. Firstly, the literature review and conceptual framework are provided based on past literature. Secondly, methodologies are explained which are applied in the study. Next part of the study is presented with the results and discussion. After that, the conclusions and implications are described for the interested parties like an internet practicing fashion apparel business, researcher, and academicians etc. Finally, the limitations and further research scope are represented.

\section{Literature Review and Conceptual Framework}

\subsection{Security factors}

Security appears to be a vast anxiety that prevents consumers from shopping internet because consumers concerned that the virtual stock will fraud them or misuse their personal information, particularly their credit card (Comegys et al., 2009). The report designated that 70 percent of US web users are extremely concerned regarding their transaction security, distinct information and misuse of private consumer data (Federal Trade Commission, 2001). E-commerce has altered the business approach and made life easier for the people of Bangladesh as well as other countries. The expert motivators for internet shopping are significant trust and loyalty, ensuring security; swift delivery service cash back assurance, cash after delivery and discount \& offers (Nazmun, 2017). Trust in the internet shopping with highly developed technology and regular internet shopping to the internet being secured as a trustworthy internet shopping media (Cuneyt \& Gautam, 2004). Website design, customer service, reliability, and security are the most important factors, which affected consumers' internet shop decision (Shergill \& Chen, 2005). Website design trust and safety can be considered as an encouraging factor that creates affirmative or off-putting feelings with a website (Zhang, et al 1999). Therefore, it is expected that:

H1: Security factors and internet shopping decision are positively related to each other.

\subsection{Delivery factors}

Since internet shopping may be anywhere and anytime, it creates consumers' life easier because consumers do not have to stick in the traffic, look for a parking spot, wait in checkout lines (Childers et al., 2001). The study is revealed that there is an inequity between internet buyers and non-internet buyers. Internet consumers are more anxious on the subject of time-saving convenience and selection whereas non-internet consumers are worried regarding security and on time delivery and privacy (Goldsmith \& Bridges, 2000). To split information and expand knowledge regarding products is influenced by internet communities (Chen, et al. 2011a). One of the key uniqueness of virtual worlds is learning by doing, which enables internet purchase consumers to learn and practice in the virtual space (Mueller, et al. 2011). Therefore, it is expected that: 
H2: Delivery factors and internet shopping decision are positively related to each other.

\subsection{Psychological factors}

The study depicted those factors in their work that influences the action of consumers. The marketing effort, socio-cultural, emotional factor, psychological factor, experience, and privacy factors are significantly influenced the purchase decision. The research also presented that consumers are influenced by several psychological factors, such as perception, attitudes motivation, personality, and emotion (Smith \& Rupp, 2003). This proposed outline not only delivers us with a cohesive view of the association between psychology and internet consumers decision but also helps as a significant guideline for investigators in this field. The exploration achieves with an examination agenda for the study of the association between psychology and internet consumers' decision (Liao \& Chung, 2014). Therefore, it is expected that:

H3: Psychological factors and internet shopping decision are positively related to each other.

\subsection{Payment approach factors}

The study showed that Small business internet shopping and payment behavior mirrors consumers' behavior. On several points, the internet payment favorites of small businesses are much related to that of consumers. Partialities initiate to depart as the SBs yearly revenue grows or as the years the small business has been in operation increase (Gourville, J. \& Soman, D. 1998). The superficial characteristics of internet shopping consisted incentive programs, site plan business deal charge, the transaction cost of the payment system and interactivity in determining the intention to purchase jewelry or accessories, clothing passing through the internet. Consumers shop the internet for the reason that easy searching and rich information about products and services (Kim, E. \& Kim, Y., 2004). Therefore, it is expected that:

H4: Payment approach factors and internet shopping decision are positively related to each other.

\subsection{Sacrifice factors}

The results show that there is a positive relationship between prices and consumers shopping behavior. The most helpful factor of shopping internet is identified as a probability to compare prices and shop at a lower price (Zivile Bauboniene, 2015). The paper is demonstrated that less time (30.12\%), low price (20.48\%) and availability of varieties (31.33\%) are the significant causes for preferring internet shopping (Mohammad, 2016). Consumers' internet shop intention is a momentous guide for operating the online organization. The major purpose of this paper is to discover the crucial aspects that influence consumers' intention, satisfaction, and loyalty towards internet shop. The study revealed that pricing is pointedly influenced internet shopping decision (Hossain, A et al., 2018). Therefore, it is expected that:

H5: Sacrifice factors and internet shopping decision are positively related to each other.

\subsection{Secrecy factors}

Secrecy information will reason consumers to integrate privacy deliberations into their internet shopping decisions. Replying that query may not only disclose a great deal regarding privacy-related consumers' behavior but also donate to a long-standing debate: whether or not industries may practice privacy purposefully, leveraging the protection of private information for competitive advantage (Brown \& Muchira, 2004). The secrecy premium is the supplementary amount of money members paid to shop from a site with a better privacy policy, as opposed to the inexpensive site for high-level secrecy for batteries is around $\$ 0.63$, while the secrecy superior for the vibrator was around $\$ 1.32$. This may designate that contributors are willing to pay around fifty cents for amplified privacy, but were unwilling to spend much more than a dollar, regardless of the nature of the item. This result may occur essential for upcoming studies that scrutinize accurately how much people are willing to pay for better privacy (Lorrie Cranor et al., 2007). Therefore, it is expected that:

H6: Secrecy factors and internet shopping decision are positively related to each other.

\subsection{Product availability factors}

Consumers shopping action towards internet shopping stores, consumers can purchase at any time and have entrance to products and lack of available in a geographic area. They are not unable to access the internet from highly developed electronic devices as it decreases the costs of product and service delivery incremental consumers aptitude and extends geographical restrictions in bringing buyers and sellers together (Mehrdad, S., 2012). The convenience factor is one of the major advantages of internet purchase. The price comparison is the convenience factor of internet purchase (Webcheck's, 1999). Internet consumers who purchase internet tend to look for variety and convenience while internet consumers were working consumer distinctiveness and internet purchase (Donthu \& Garcia, 1999). Therefore, it is expected that: 
H7: Product availability factors and internet shopping decision are positively related to each other.

\subsection{Product variety factors}

Product variety is a vital factor when it comes to intention in internet shop (Szymanki \& Hise, 2000). Product variety, Price and product quality are most leading and dominating perceptions when it comes to consumers' internet shop (Arnold, et al., 1996). There is a continuous rise in internet shopping in the US and there has been an increasing impact in the total amount of retail sales as well, thus calling for more extensive exploration of spending patterns per person. In order to buy more products online. There be several product categories and a diverse range when they are being sold internet (Peterson, et al. 1997). Therefore, it is expected that:

H8: Product variety factors and internet shopping decision are positively related to each other.

\subsection{Promotional factors}

The exploration found that T.V. Advertisement (20.48\%), website advertising (45.78\%), family members $(15.66 \%)$ and friends are the vital media all the way through which consumers became familiar towards internet shopping (Mohammad, 2016). The study scrutinizes influence of deal proneness on Indian consumers' internet shopping decision. The outcomes indicate that Indian consumers are not influenced by deals, offers or other promotional tools being used by internet retailers. Promotions may not be necessarily noticed by consumers as a vital attribute while buying products or services internet (Rakesh \& Khare, 2012). Long-term influence of coupons on brand value differs across deal categories, and non-monetary promotions had an affirmative effect on brand value as compared with financial promotions. Less deal-prone shoppers show significant differences in their attitudes towards financial and non-financial promotions as compared with strong deal-prone shoppers (Yi \& Yoo, 2011). This investigation is exposed that consumers' perceptions towards gift promotions. The assessment of gift promotions is affirmative when the general brand equity of the product encouraged is high and the fit between product encouraged and the gift is high (Montaner et al., 2011). Therefore, it is expected that:

H9: Promotional factors and internet shopping decision are positively related to each other.

\subsection{Internet shopping decision}

Internet shopping is a significant trade model in e-commerce. If the internet sellers want to convince and retain internet consumer, they need to know what the issues internet buyers use to decide their internet shop and satisfaction. Product quality and consumers satisfaction are both interrelated in an internet shop. The performance of a brand meets the expectations of the consumer when satisfaction occurs. Brand may be influenced satisfaction (He, Li \& Harris, 2012). Highly satisfied consumers are likely to reflect the brand personality traits by using some symbols interrelated to the brand as an expression of their addition to that brand (Chiu et al., 2010). The period of a relationship between an internet consumer and a seller is longer when the internet consumer is satisfied (Bolton, 1998). Therefore, it is expected that:

H10: Internet shopping decision and satisfaction are positively related to each other.

\subsection{Conceptual framework}

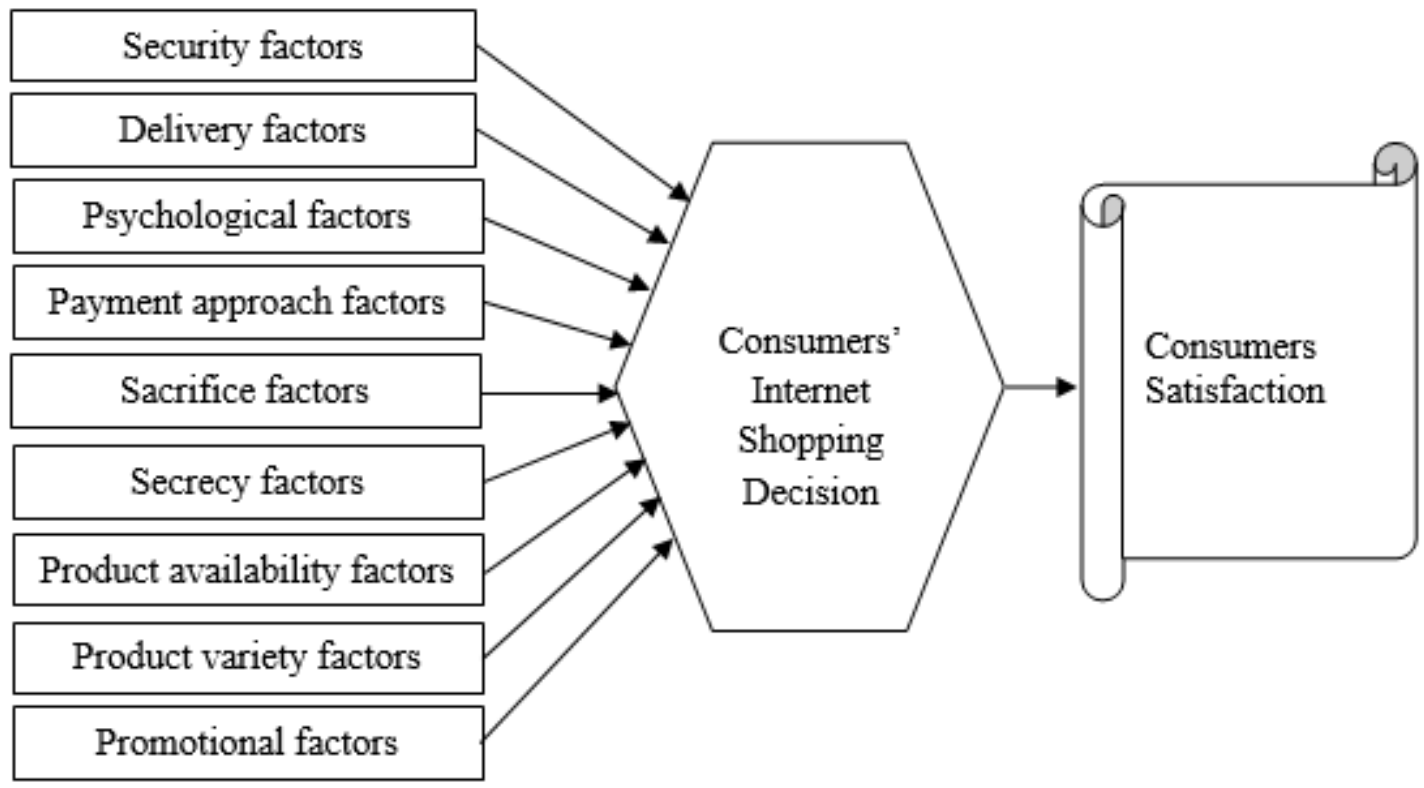

Source: Developed by the researchers

Figure 1. Proposed research model 


\section{Research Methodology}

This paper is quantitative. The type of information that is essential for this study is mostly primary in nature and all data have been collected from primary sources by the personal interview method. On the other hand, from the secondary sources, literature review has been developed. Structural questions have prepared consists of 16 questions for data collections. Five questions are related to demographic variables such as age, gender, occupation, education qualification, and monthly income. Eleven questions are about the consumers' internet shopping decision toward fashion apparels and its impact on satisfaction by using Likert scales (from $1=$ 'Strongly disagree' to $5=$ 'Strongly agree'), those questions are such as: security factors, delivery factors, psychological factors, payment approach factors, sacrifice factors, privacy factors, product availability factors, product variety factors, promotional factors, shopping decision and satisfaction. Convenience sampling method has been used because it is, convenient, readily available and generates a relatively low cost. Primary data is collected through the personal interview from 200 respondents. All constructs have no problems in reliabilities if the Cronbach's Alpha values exceeded the criterion of 0.700. Cronbach's Alpha is 0.773 for 11 items of a variable, which suggests that the survey instrument is reliable to measure all constructs consistently and free from random error. Data collected from questionnaires are analyzed by using various statistical tools like frequency and regression analysis by using SPSS 20.0.

\section{Results and Discussions}

Table 1. Model Summary

\begin{tabular}{|c|c|c|c|c|}
\hline Model & R & R Square & Adjusted R Square & Std. Error of the Estimate \\
\hline 1 & $.568 \mathrm{a}$ & .322 & .290 & 1.02314 \\
\hline
\end{tabular}

Source: Researchers field data

\subsection{Level of the relationship between factors and shopping decision}

Table 1 presents that correlation coefficient value $(R)$ is equal to 0.568 which suggests that there is a moderate positive relationship between shopping decision of fashion apparels and security, delivery, psychological, payment approach, sacrifice, secrecy, product availability, product variety, promotional aspects. However, only $32.2 \%$ (R-square values of 0.322 ) variation in consumers' shopping decision of fashion apparels is accounted due to security, delivery, psychological, payment approach, sacrifice, secrecy, product availability, product variety, and promotional aspects.

Table 2. ANOVA

\begin{tabular}{|c|l|c|c|c|c|c|}
\hline \multicolumn{2}{|c|}{ Model } & Sum of Squares & Df & Mean Square & F & Sig. \\
\hline \multirow{4}{*}{1} & Regression & 94.606 & 9 & 10.512 & 10.042 & $.000 \mathrm{~b}$ \\
\cline { 2 - 8 } & Residual & 198.894 & 190 & 1.047 & & \\
\cline { 2 - 8 } & Total & 293.500 & 199 & & & \\
\hline
\end{tabular}

Source: Researchers field data

\subsection{Confirm the model fitness}

Table 2 reveals that multiple regression analysis is performed to scrutinize the association between security, delivery, psychological, payment approach, sacrifice, secrecy, product availability, product variety, and promotional with shopping decision of fashion apparels. Nine hypotheses are proposed and results are enumerated in Table 2. The F-statistics produced $(\mathrm{F}=10.042)$ is significant at 1 percent level $(\mathrm{Sig} . \mathrm{F}<0.01)$ with 9 and 190 degrees of freedom, therefore confirming the fitness for the model. The adjusted (R2) is 0.290 (From Table 1), connoting that the nine factors can significantly account for $29.0 \%$ variance in consumers' internet shopping decision of fashion apparels.

Table 3. Coefficients

\begin{tabular}{|c|c|c|c|c|c|c|}
\hline & \multirow{2}{*}{ Model } & \multicolumn{2}{|c|}{ Unstandardized Coefficients } & \multirow{2}{*}{$\frac{\text { Standardized Coefficients }}{\text { Beta }}$} & \multirow{2}{*}{$\mathbf{T}$} & \multirow{2}{*}{ Sig. } \\
\hline & & B & Std. Error & & & \\
\hline & (Constant) & .558 & .432 & & 1.291 & .198 \\
\hline \multirow{9}{*}{1} & Security factors & .255 & .080 & .245 & 3.180 & .002 \\
\hline & Delivery factors & .395 & .107 & .375 & 3.675 & .000 \\
\hline & Psychological factors & -.035 & .154 & -.024 & -.229 & .819 \\
\hline & Payment approach factors & -.013 & .075 & -.012 & -.169 & .866 \\
\hline & Sacrifice factors & .037 & .093 & .035 & .395 & .693 \\
\hline & Secrecy factors & .136 & .132 & .090 & 1.037 & .301 \\
\hline & Product availability factors & .213 & 074 & .205 & 2.850 & .005 \\
\hline & Product variety factors & .271 & .077 & .261 & 3.510 & .001 \\
\hline & Promotional factors & .051 & .077 & -.050 & -.656 & .513 \\
\hline
\end{tabular}

Source: Researchers field data 


\subsection{Influential factors of internet shopping decision toward fashion apparels}

The results of multiple regression analysis for $\mathrm{H} 1$ as presents in Table 3 that security as the major factor, which positively and significantly influences consumers' internet shopping decision of fashion apparels $(\beta 1=0.245$; $\mathrm{t}$ value $=3.180 ; \mathrm{p}<0.05)$. H1 is accepted. Therefore, security is influenced consumers' internet shopping decision of fashion apparels. The results for $\mathrm{H} 2$ as shows that delivery as the vital factor, which positively and notably influences consumers' internet shopping decision of fashion apparels $(\beta 2=0.375$; $\mathrm{t}$-value $=3.675 ; \mathrm{p}$ $<0.05)$. H2 is accepted. Hence, delivery is influenced consumers' shopping decision of fashion apparels. Next, H7 substantiates that product availability as the key factor, which positively and significantly influences consumers' internet shopping decision of fashion apparels $(\beta 7=.205$; $\mathrm{t}$-value $=2.850, \mathrm{p}<0.05)$. H7 is accepted. For this reason, product availability is influenced consumers' internet shopping decision of fashion apparels. Then, $\mathrm{H} 8$ presents that product variety as the major factor, which positively and considerably influences consumers' internet shopping decision of fashion apparels $(\beta 8=.261$; t-value $=3.510 ; \mathrm{p}<0.05)$. $\mathrm{H} 8$ is accepted. Thus, product variety is influenced consumers' internet shopping decision of fashion apparels.

The outcomes in Table 3 corroborates that psychological aspects negatively and insignificantly influence consumers' internet shopping decision of fashion apparels $(\beta 3=.024 ; \mathrm{t}$-value $=.229 ; \mathrm{p}>0.05)$. H3 is not accepted. So, psychological aspects have no effect consumers' internet shopping decision of fashion apparels. Next, H4 substantiates that payment approach negatively and insignificantly influences consumers' shopping decision of fashion apparels $(\beta 4=-.012 ; \mathrm{t}$-value $=-.169 ; \mathrm{p}>0.05)$. H4 is not accepted. Therefore, payment approach has no effects consumers' internet shopping decision of fashion apparels. Then, H5 substantiates that sacrifice factors insignificantly influence consumers' internet shopping decision of fashion apparels $(\beta 5=.035$; $\mathrm{t}$-value $=.395 ; \mathrm{p}>0.05)$. H5 is not accepted. Thus, sacrifice aspects have no effect consumers' internet shopping decision of fashion apparels. Next, H6 substantiates that secrecy factors negatively and insignificantly influence consumers' internet shopping decision of fashion apparels ( $\beta 6=.090$; t-value $=1.037$; $\mathrm{p}>0.05)$. H6 is not accepted. As a result, secrecy has no effects on consumers' internet shopping decision of fashion apparels. Last one, H9 substantiates that promotional factors negatively and insignificantly influence consumers' internet shopping decision of fashion apparels $(\beta 9=-.050$; t-value $=-.656 ; p>0.05)$. H9 is not also accepted. Hence, promotional have no effect consumers' internet shopping decision of fashion apparels.

Table 4. Model Summary

\begin{tabular}{|c|c|c|c|c|}
\hline Model & R & R Square & Adjusted R Square & Std. Error of the Estimate \\
\hline 1 & $.308 \mathrm{a}$ & .095 & .090 & 1.01145 \\
\hline
\end{tabular}

\subsection{Level of the relationship between shopping decision and satisfaction}

Table 4 exposes that correlation coefficient value (R) is equal to 0.308 which recommends that there is a moderate positive correlation between satisfaction and consumers shopping decision of fashion apparels. However, only $9.5 \%$ (R-square values of 0.095 ) variation in recommending is accounted due to consumers' internet shopping decision of fashion apparels.

Table 5. ANOVA

\begin{tabular}{|c|l|c|c|c|c|c|}
\hline \multicolumn{2}{|c|}{ Model } & Sum of Squares & Df & Mean Square & F & Sig. \\
\hline \multirow{3}{*}{1} & Regression & 21.234 & 1 & 21.234 & 20.756 & $.000^{\mathrm{b}}$ \\
\cline { 2 - 8 } & Residual & 202.561 & 198 & 1.023 & & \\
\cline { 2 - 8 } & Total & 223.795 & 199 & & & \\
\hline
\end{tabular}

Source: Researchers field data

\subsection{Confirm the model fitness}

Table 5 reveals that multiple regression analysis is performed to scrutinize the association between consumers' internet shopping decision of fashion apparels and satisfaction on fashion apparels. One hypothesis is proposed and results are enumerated in Table 5. The F-statistics produced $(\mathrm{F}=20.756)$ is significant at 1 percent level (Sig. F < 0.01) with 1 and 198 degrees of freedom, so confirming the fitness for the model. The adjusted (R2) is 0.090 (From table 4), connoting that the one factor can significantly account for $9.0 \%$ variance in consumers satisfaction on fashion apparels.

Table 6. Coefficients

\begin{tabular}{|c|c|c|c|c|c|c|}
\hline \multirow{2}{*}{\multicolumn{2}{|c|}{ Model }} & \multicolumn{2}{|c|}{ Unstandardized Coefficients } & \multirow{2}{*}{$\begin{array}{c}\text { Standardized Coefficients } \\
\text { Beta } \\
\end{array}$} & \multirow{2}{*}{$\mathbf{T}$} & \multirow{2}{*}{ Sig. } \\
\hline & & $\mathbf{B}$ & Std. Error & & & \\
\hline \multirow{2}{*}{1} & (Constant) & 2.592 & .242 & & 10.718 & .000 \\
\hline & Internet shopping decision & .317 & .069 & .308 & 4.556 & .000 \\
\hline
\end{tabular}

Source: Researchers field data 


\subsection{Internet shopping decision influences satisfaction on fashion apparels}

The results of multiple regression analysis as demonstrates in Table 6 internet shopping decision of fashion apparels as the crucial factor, which significantly affects satisfaction on fashion apparels $(\beta 10=0.308$; t-value $=4.556 ; \mathrm{p}<0.05)$. H10 is supported. Therefore, internet shopping decision of fashion apparels is significantly affected satisfaction with fashion apparels.

Table 7. The demographic profile of respondents

\begin{tabular}{|l|c|c|}
\hline \multicolumn{1}{|c|}{ Variable } & Frequency & Percentage \\
\hline Age & & 50 \\
15-30 Years & 100 & 30 \\
30-45 Years & 60 & 17.5 \\
45-65 Years & 35 & 2.5 \\
65 Years + & 5 & 45 \\
\hline Gender & 90 & 55 \\
Male & 110 & 40 \\
Female & & 20 \\
\hline Occupation & 80 & 40 \\
In service & 40 & 10 \\
Business & 80 & 5 \\
Students & 20 & 15 \\
Others & & 50 \\
\hline Education Qualification & 10 & 20 \\
SSC & 30 & 10 \\
HSC & 100 & 45 \\
Graduate & 40 & 40 \\
Post-graduate & 20 & 10 \\
Others & & 5 \\
\hline Monthly Income & 90 & \\
Below 20,000 & 80 & \\
20,000-50,000 & 20 & \\
50,000-80,000 & 10 & \\
80,0000 above & & \\
\hline
\end{tabular}

Source: Researchers field data

\subsection{The demographic profile of respondents}

Table 7 presents the descriptive investigation on the demographic profile of respondents. It appears that respondents are mostly in the age categories 15-30 years old (50\%). The second highest of respondents are in the age categories 30-45 years (30\%). The third highest of respondents are in the age categories 45-65 years $(17.5 \%)$ and the minority of respondents are in the age categories 65 years above $(2.55 \%)$. The majority of respondents are female (55\%) with male constituting (45\%). With regard to occupation status, the majority of respondents are both In service and Students (40\%), the second highest of respondents are Business (20\%), and the minority of respondents are others $(10 \%)$. With regards to educational qualification, $50 \%$ of respondents are Graduate, $20 \%$ respondents are Postgraduate, $15 \%$ of respondents are HSC, $10 \%$ of respondents are Others degree, and 5\% of the respondents are SSC. It presents that respondents are the majority in the income level below 20, $000(45 \%)$, the second highest of respondents are income level 20,000-50,000 $(40 \%)$, the third highest of respondents are income level 50,000-80,000 (10\%) and the minority of respondents are income level 80,000 above $(5 \%)$.

\section{Conclusion and Implications}

The apparel business in Bangladesh has been expanded almost repeatedly since the late 1970s. There are three potential strengths like dynamism inside the business, market power, and government policy. The significance of business advancement as an engine of Bangladesh's economic growth is also strengthened by an increasing comprehension that the growth of apparel sector, one of the backbones of the country's economy, unsympathetically pivots on its backward and forward connection with the industrial area. Within a single period apparels business in Bangladesh has developed as the single leading business in the export arena: the business set its profile with four billion dollars in gross value terms and employment scopes of more than million skilled and semi-skilled females' employees. Typically administrations in less industrialized nations are weak and always lack appropriate timing and synchronization with respect to generating helpful policy government for favorable growth of developing business. From that viewpoint, the role of successive régimes to uphold the RMG industry in Bangladesh is fairly notable. It is well-intentioned to note that the first export delivery of shirts from Bangladesh made by the state-trading agency, the Trading Corporation of Bangladesh, in the mid-1970s was destined to some East European nations under countertrade arrangements. In Bangladesh, internet shopping would acquire more concern from customers since obtaining from web give several benefits to shoppers. Internet shopping is an easy solution for a busy life in today's world. In the past decade, there had 
been a massive change in the method of consumer's shopping. Despite consumers' continuation to purchase from a physical store, the users or purchasers feel very suitable for virtual shopping. Internet shopping protects key time for contemporary publics because they get so busy that they unwilling to spend much time shopping. Consumers show significantly higher intention to shop for fashion apparel through the internet with innovative market incentives confirming relative benefits of internet apparel shopping that may be available in today's internet retail places. This paper has been undertaken with an aim to analyze the consumers' internet shopping decision toward fashion apparels and its impact on satisfaction. Some factors are momentous tools to influence consumers' internet shopping decision toward fashion apparels and its impact on satisfaction. This paper discovers security, delivery, psychological, payment approach, sacrifice, secrecy, product availability, product variety, and promotional aspects are likely factors that influence consumers' internet shopping decision of fashion apparels and its impact on satisfaction. From the results of regression analysis, this research is found that security, delivery, product availability, and product variety as the important factors, which significantly influence consumers' internet shopping decision of fashion apparels. This paper discovered that internet shopping decision of fashion apparels as the important factor, which significantly influences consumers' satisfaction in fashion apparels. This paper presented that consumers face problems in shopping of fashion apparels through the internet. From the results of regression analysis, psychological factors, payment approach, sacrifice factors, secrecy factors, and promotional aspects don't influence consumers' internet shopping decision of fashion apparels. This paper may be added to these internet shopping focuses on fashion apparels. Internet functioning fashion apparels organization can be promoted recognizing persuasive factors of internet shopping decision and satisfaction on fashion apparels. It can aid internet shopping decision of fashion apparels and satisfaction on fashion apparels excellence along with numerous apparels offer to virtual consumers through the internet. This exploration will be created awareness among e-business practicing fashion apparels firms, academicians, researchers, and virtual fashion apparels shoppers.

\section{Limitation and Further Study}

This data may not be the real representative of overall Bangladeshi internet consumers because of sample area and size. These results may not be applicable to other places. This investigation found some influential independent variable and the study is conducted in Dhaka city and specific sector that is a national small portion. In a matter of fact, there may be some other variable and the study will be conducted in a larger area. Those elements are left for future exploration.

\section{References}

1. Arnold, S. J., Handelman, J. and Tiger, D. J. (1996). Organizational legitimacy and retail store Patronage. Journal of Business Research, 35(3), 229-239.

2. Bélanger, F., Janine, H. and Smith, W. (2002). Trustworthiness in electronic Commerce: The role of privacy, security, and site attributes. Journal of Strategic Information Systems, 11, 245-70. Available at: http://www.elsevier.com/locate/jsis.

3. Bolton, R. N. (1998). A dynamic model of the duration of the customer's relationship with continuous service provider the role of satisfaction. Marketing Science, 17(1), 45-65.

4. Brown, M. and Muchira, R. (2004). Investigating the Relationship between Internet Privacy Concerns and Online Purchase Behavior. Journal of Electronic Commerce Research, 5(1), 62-70.

5. Bulbul, A. (2015). Consumers' attitude towards e-commerce in Bangladesh: An empirical study on some selected b2c e-commerce sites. Journal of Business and Technology, 10(1), 71-76.

6. Chen, Xu, H. and Whinston, A. B. (2011). Moderated online communities and quality of user-generated content. Journal of Management Information Systems, 28(2), 237-68.

7. Childers, T.L., Carr, C.L., Peck, J. and Carson, S. (2001). Hedonic and utilitarian motivations for online retail shopping behavior. Journal of Retailing, 77(4), 511-535.

8. Chiu, Huang, H. Y. and Yen, C. H. (2010). Antecedents of online trust in online auctions. Electronic Commerce Research and Application, 9(2), 148-159.

9. Chiu, Lin, C. P. and Tang, L. L. (2005). Gender differs: assessing a model of online purchase intentions in e-tail service. International Journal of Service Industry Management, 16(5), 416-635.

10.Comegys, C., Hannula, M. and Váisánen, J. (2009). Effects of consumer trust and risk on online purchase decision-making: A comparison of Finnish and United States students. International Journal of Management, 26(2), 295-308.

11.Cuneyt, K. and Gautam, B. (2004). The impacts of quickness, price, payment risk and delivery issues on on-line shopping. Journal of Socio-Economics, 33(2), 241-251.

12.Donthu, N. and Garcia, A. (1999). The internet shopper. Journal of Advertising Research, 39(3), 52-59.

13.Federal Trade Commission (2001). Privacy Leadership Initiative. Available at: http://www.ftc.gov/ bcp/workshops/glb/supporting/ Harris\%20results.pdf, FTC.gov. 
14.Goldsmith, R. E. and Bridges, E. (2000). Using attitudes to predict online buying behavior. Quarterly Journal of Electronic Commerce, 1, 245-253.

15.Gourville, J., \& Soman, D. (1998). Payment depreciation: The behavioral effects of temporally separating payments from consumption. Journal of Consumer Research, 25(2), 160-174.

16.Hahn, L., Hoelzl, E., \& Pollai, M. (2013). The effect of payment type on product-related emotions: evidence from an experimental study. International Journal of Consumer Studies, 37(1), 21-28.

17.He, H., Li, Y. and Harris, L. (2012). Social identity perspective on brand loyalty. Journal of Business Research, 65(5), 648-57.

18.Hossain, A., Jamil, Md. A. A and Rahman, Md. M., (2018). Exploring the Key Factors Influencing Consumers' Intention, Satisfaction and Loyalty towards Online Purchase in Bangladesh. International Journal of Economics and Financial Research, 4(7), 214-225.

19.Jubayer, S. (2015). Acceptance of online shopping in Bangladesh: Consumer's perspective. Journal of Business and Management: Available at: http://www.iosrjournals.org.

20.Kim, E. and Kim, Y. (2004). Predicting online purchase intention for clothing products. European Journal of Marketing, 38(7), 833-97.

21.Liao and Chung (2014). The Effects of Psychological Factors on Online Consumer Behavior. National Science Council, Taiwan, Republic of China, under contract No. NSC 98-2410-H-032 -038-MY2.

22.Lorrie Cranor, Serge and Egelman (2007). The Effect of Online Privacy Information on Purchasing Behavior: An Experimental Study. International Conference on Information Systems, 5(1), 21-29.

23.Mehrdad, S. (2012). Consumer buying behavior towards internet shopping stores. International Journal of Academic Research in Business and Social Sciences, 2(1). ISNN: 2222-6990.

24.Mohammad, T. R. (2016). Consumers' attitude towards online shopping the case of Bangladesh. World Journal of Social Sciences, 6(2), 82-91.

25.Mohd, S. (2017). A literature review of the trend of electronic commerce in Bangladesh perspective economics and commerce. Global Journal of Management and Business Research, 17(3). Available at: https://journalofbusiness.org/index.php/GJMBR/article/view/2257.

26. Montaner, Chernatony and Buil, (2011). Consumer response to gift promotions. Journal of Product \& Brand Management, 20(2), 101-110.

27.Mueller, J., Hutter, K., Fueller, J. and ScMatzler, K. (2011). Virtual worlds as knowledge management platform - a practice-perspective. Information Systems Journal, 21(6), 479-501.

28.Nazmu, N. M. (2017). A literature review of the trend of electronic commerce in Bangladesh perspective. Global Journals Inc (USA), 17(3). Available at: https://journalofbusiness.org/index.php/GJMBR/article/view/2257 Owens.

29.Peterson, R. A., Balasubramanian, S. \& Bronnenberg, B. J. (1997). Exploring the implications of the Internet for consumer marketing. Journal of the Academy of Marketing Science, 25(4), 329-346.

30.Qazi, M. M. (2014). Factors influencing consumers' attitude towards online shopping evidence from Dhaka City. Journal of Business Studies, 25(3), 161-47. Available at: https://www.fbsdu.com/news_event/14664880988.pdf.

31.Rakesh and Khare (2012). Impact of promotions and value consciousness in online shopping behaviour in India. Journal of Database Marketing \& Customer Strategy Management, 19(4), 311-320.

32.Shergill, G. S. and Chen, Z. (2005). Web-based shopping Consumers attitudes towards online shopping in New Zealand. Journal of Electronic Commerce Research, 6(2), 79-94.

33.Sien (2015). Factors Influencing consumers purchase intention towards online group buying in Malaysia. Available at: http://www.eprints.utar.edu.my/id/eprint/2161.

34.Smith, D. A. \& Rupp, T. W. (2003). Strategic internet customer decision making: leveraging the Transformational power of the Internet. Internet Information Review, 27(6), 418-432.

35.Szymanski, D. M. \& Hise, R.T. (2000). E-satisfaction: An initial examination. Journal of Retailing, 76(3), 309-322.

36.Webcheck (1999). Marketing and selling to the South African web user. Retrieved 26 September 2018 from http://www.webckeck.co.za.

37. Yi and Yoo (2011). The long-term effects of sales promotions on brand attitude across monetary and nonmonetary promotions. Psychology and Marketing, 28(9), 879-896.

38.Zhang, P., Von, D. G. M., Small, R. V. and Barcellos, S. (1999). Websites that Satisfy Users: A Theoretical Framework for Web User Interface Design and Evaluation. Proceedings of the 32nd Hawaii International Conference on System Sciences.

39.Zivile Bauboniene (2015). E-commerce factors influencing consumers' online shopping decision. Social Technologies Research Journal, 5(1), 74-81. 